\title{
A Magyar statisztikai évkönụv szerkezetének változásai 1872 és 2016 között
}

\section{Lencsés Ákos,}

a Magyar Tudományos Akadémia Könyvtár és Információs Központ fökönyvtárosa

E-mail:

lencses.akos@konyvtar.mta.hu
A Magyar statisztikai évkönyv a KSH (Központi Statisztikai Hivatal) 1872 óta megjelenő reprezentatív kiadványsorozata. Az évek során az évkönyvben bekövetkezett változások fontos szeletét adják a magyar statisztika történetének. A kiadványok táblázatszintü vizsgálata segítséget nyújthat annak azonosításában, hogy az egyes korszakokban mely szakstatisztikákra irányult nagyobb figyelem.

Jelen elemzés azt méri fel, hogy az évkönyvekben a különböző szakstatisztikák hány táblázattal szerepelnek. A szerző a rendelkezésre álló adatok alapján bemutatja a gazdaságstatisztika, valamint a társadalomés népesedésstatisztika egymáshoz viszonyított arányát, illetve egyes kiemelt szakstatisztikák arányváltozásait az elmúlt 150 évben.

TÁRGYSZÓ:

Statisztikai kiadvány.

Statisztikai évkönyv.

Szakstatisztika.

DOI: $10.20311 /$ stat2017.11-12.hu1144 
A Magyar statisztikai évkönyv a KSH (Központi Statisztikai Hivatal) mindenkori reprezentatív kiadványsorozata. Keleti Károly már a hivatal alapításakor fontos célkitüzésnek tekintette egy statisztikai évkönyv rendszeres megjelentetését, melynek megvalósításáról törvényjavaslatában külön pont szólt. A kiadvány fontosságát többek között akadémiai székfoglalójában is hangsúlyozta (Keleti [1868], [1869]).

Az 1872 óta kiadott évkönyvek szerkezete bemutatja az intézmény által vizsgált statisztikai területeket, a szervezet mindenkori müködési körét. Így a kötetek szerkezeti változása, a publikálásra kiválasztott 400-600 táblázat összetétele iránymutatást adhat arra vonatkozóan, hogy egy-egy időszakban a KSH mely témaköröket tartotta leglényegesebbnek tevékenysége szempontjából.

A statisztikai évkönyvekkel kiemelt fontosságuk ellenére meglepöen kevés elemzés foglalkozik. Ismertetésükre a statisztikai hivatal kezdeti időszakában a kiadványpolitikát átfogóan bemutató írásokban tértek ki, részletes elemzésükre azonban nem került sor (György [1885], Bokor [1896]). Az egyetlen, nyilvános publikációban is napvilágot látott átfogó elemzést Surányi-Unger Tivadar 1944-ben közölte a Magyar Statisztikai Szemlében (Surányi-Unger [1944]). A Surányi-Unger vezetésével müködő bizottság célja a statisztikai évkönyv megreformálása volt. Bár a tanulmány a szerkezeti és tartalmi kérdések mellett alapos, tipográfiai és nyomdai jellemzőkre kiterjedő, illetve nemzetközi összehasonlítást is felvonultató elemzést ad a magyar évkönyvekről, Surányi-Unger észrevételeit 1945 után nem vették figyelembe, javaslatait szinte kivétel nélkül figyelmen kívül hagyták. A második világháborút követően is hajtottak végre az évkönyvek szerkezetére vonatkozó vizsgálatokat, azonban ezek eredményei sem a nagyközönség, sem a kutatói közösség számára nem voltak hozzáférhetők.

Jelen írás célja a statisztikai évkönyvek szerkezeti változásainak felmérése. Az adatok alapján igyekszünk következtetéseket levonni arra vonatkozóan, hogy mely témák, adatkörök voltak a legkeresettebbek, és melyekkel foglalkozott kisebb mértékben a statisztikai hivatal 1872 és 2016 között. Bár a KSH bemutatkozó kiadványaiban mindig hangsúlyozta az egyes statisztikai ágak egyenrangúságát (KSH [1986], [1991], [1997], [2010]), az évkönyvekben - és általában a statisztikai irodalomban - egyes korszakokban más és más szakstatisztikák élveztek elsőbbséget. Vizsgálatunk célja ezért annak megállapítása, hogy ezt vajon alátámasztják-e a hivatal működésének (néhány évet leszámítva) teljes időszakát lefedő évkönyvek témaköreiben és táblázatainak témakörönként vett számában tapasztalt változások is. 


\section{Történeti áttekintés}

Az elsö, 1870-es években megjelent kötetek (címükben még statistikai és nem statisztikai évkönyvek) nem a mai követelményeknek megfelelöen jelentek meg. A korai kiadványokat címükben tárgyév megjelölése nélkül, az egyes fejezetekben eltérő tárgyévet közölve adták ki. A negyedik évfolyamtól a hivatal füzetes jelleggel kezdte publikálni őket, így azok lényegében fejezetenként láttak napvilágot az év során, az egyes füzeteket pedig év végén lehetett egybekötni. Jó esetben ily módon elóállt az adott évre vonatkozó statisztikai évkönyv (György [1885], Bokor [1896]). Az évkönyv megjelenési nehézségei és más problémák miatt a hivatal mellett - olyakor azzal együttmüködve - más szervezetek is közzétetettek statisztikai kiadványokat: például az MTA Statisztikai és Nemzetgazdasági Bizottság 1883 és 1886 között a Nemzetgazdasági és statisztikai évkönyvet, illetve 1887-töl 1896-ig a statisztikai hivatallal közösen a Közgazdasági és statisztikai évkönyvet.

1889 és 1893 között nem adták ki a Magyar statisztikai évkönyvet. 1893-ban azonban az új folyam már a mai követelményeknek is megfelelt szerkezetét és rendszeres megjelenését illetően, viszont a táblázatokon kívül nem tartalmazott módszertani jegyzeteket, illetve nem utalt adatforrásra vagy további forrásmüvekre. A kezdeti időszakban tudatosan kerülték a módszertani jegyzeteket. Ahogyan György Aladár írja a ma már különösnek ható helyzetről: „,...magyarázatok a világos áttekintést nyujtó táblázatok mellett lehetöleg kerültettek..." (György [1885] 41. old.) A módszertani megjegyzések végül az 1940-es években nyertek teljes létjogosultságot a kiadványokban.

Az első világháború kezdetén kis mértékben átalakult az évkönyv szerkezete. A változások elsősorban az idősoros és a területi adatokat érintették (Buday [1915]), a témaköröket kevésbé. A háború elörehaladtával az évkönyv a papírhiányra hivatkozva gazdasági okokból, illetve az adatgyüjtések ellehetetlenülése miatt szerkezetileg is nagyban módosult (Szabóky [1924]).

A két világháború közötti időszakban a kiadvány szerkezete stabilnak mondható - ha nem is olyan mértékben, mint a század második felének egyes időszakaiban. A második világháborút megelőző években az ország területi változásai jelentettek elsősorban kihívást, ugyanis jelentős feladatot volt az évkönyvbe beépíteni a visszacsatolt területekre vonatkozó adatokat (Dobrovits [1940]). Ebben az időszakban az egyes évekre általában összevonva, utólag jelentettek meg kiadványokat.

A második világháborút követően, egészen az 1950-es évek második feléig a kiadott statisztikai évkönyvek nem voltak nyilvánosak. 1948-ban a „Magyar statisztikai évkönyv" címet Statisztikai évkönyvre változtatták. (Hasonló átnevezés figyelhető meg a Magyar Statisztikai Szemle esetén is, amelyet 1948-tól "Statisztikai Szemle” címmel adnak ki.) A névváltozással tartalmi módosulások is jártak: az évkönyv szerkezetét a szocialista statisztika elvárásaihoz kellett igazítani. Vízválasztónak tekint- 
hetők ebből a szempontból az 1947., 1948. és 1949. tárgyévi kötetek, amelyekben jelentős strukturális átalakítást hajtottak végre. Ezek a változások adtak lehetőséget a hivatalnak arra, hogy az évkönyvet csak kézirat gyanánt és ne nyilvános kiadványként publikálja (Pikler [1949]). Nyilvános használatra csak az 1950-es évek második felétől adták ki újra.

A szocializmus időszakában az évkönyvek szerkezete állandónak mondható, bár többször jelentek meg a kötetekben, illetve tűntek el azokból egyes témakörök. Gyakori volt a témakörök olykor meglehetősen hektikus összevonása és szétválasztása is.

1989 után is több szerkezeti változás figyelhető meg, leginkább egy-egy új témakör beépítése miatt. Ezek természetesen nem csak a fejezetek esetén jelentettek módosulást: 1990-ben visszaállították a „Magyar statisztikai évkönyv” címet, 1992-ben pedig napvilágot látott az első magyar-angol kétnyelvủ kötet. Bár az évkönyv már 1997 óta megjelent (a nyomtatott kötettöl függetlenül) CD-formában is, 2005-ben először adták ki nyomtatott változatát $\mathrm{CD}$-melléklettel. A következő években több adatkör is a CD-mellékletre szorult, és a továbbiakban nem került nyomtatásba (Vukovich [2010]). A CD-mellékletet 2012-ben online melléklet váltotta fel: napjainkban a kiadványban található kóddal lehet hozzáférni a KSH honlapján a nyomtatásban nem megjelent részekhez (Vukovich [2013]). Bár az évkönyvben szereplő adatok mind szabadon elérhetők a KSH honlapján, az online évkönyvek fizetős konstrukcióban történő közzététele némiképp szembemegy a nyílt hozzáférés egyre inkább elterjedő módszerével. ${ }^{1}$

\section{A Magyar statisztikai évkönyv szerkezeti vizsgálata}

A szerkezeti vizsgálat során a fejezeteket tematikai kategóriákba soroltuk. Nagy kérdés a helyes kategóriarendszer meghatározása. A statisztikai hivatal jelenleg a nemzetközileg elfogadott standardok szerint rendszerezi kiadványait, azonban ennek a tematikának a következetes alkalmazása meglehetősen nehéz a tizenkilencedik században megjelent évkönyvek esetén. Ezért felmerült a KSH Könyvtár egyénileg kialakított, zárt tárgyszórendszerének használata. Ez a könyvtári gyakorlatnak meg-

\footnotetext{
${ }^{1}$ Harmincegy európai statisztikai hivatal gyakorlatát áttekintve kilenc ország nem jelentet meg statisztikai évkönyvet (Belgium, Franciaország, Görögország, Hollandia, Izland, Egyesült Királyság, Norvégia, Svédország, Szlovénia). A statisztikai évkönyvet kiadó huszonkét ország közül mindössze Magyarország, Románia, Svájc és Szlovákia nem teszi a megjelenés pillanatában szabadon hozzáférhetővé az online változatot, Albánia, Ausztria, Bulgária, Csehország, Dánia, Észtország, Fehéroroszország, Finnország, Horvátország, Írország, Lengyelország, Lettország, Litvánia, Németország, Olaszország, Oroszország, Portugália és Spanyolország hivatalai nyílt hozzáféréssel teszik azt elérhetővé.
}

Statisztikai Szemle, 95. évfolyam 11-12. szám 
felelően egy-egy témakörhöz 3-10 tárgyszót rendel, amelyek közül nem lehet egyértelmúen kiválasztani a fejezetek számára legrelevánsabb tartalmi jelölőt. A nemzetközi gyakorlatban számos egyéb statisztikai tárgyszórendszer és tezaurusz is létezik, ezek azonban túlságosan részletesek ahhoz, hogy alkalmazásukkal vizsgálatunk értékelhető eredményt adjon. Ezért a tárgyszórendszereket elvetve, a KSH által napjainkban használt tematikai kategóriákkal dolgoztunk. (Természetesen tisztában vagyunk azzal, hogy ez a beosztás a korai kiadványok esetén torzíthatja az adatokat.)

Az évkönyvek fejezeteit és táblázatait egy-egy altémakörbe soroltuk, ami meghatározza a témakört és a fö témakört is.

1. táblázat

\begin{tabular}{|c|c|c|}
\hline Fö témakör & Témakör & Altémakör \\
\hline \multirow{10}{*}{ Népesedés- és társadalomstatisztika } & \multirow{2}{*}{ Népesedésstatisztika } & Népesség \\
\hline & & Népmozgalom \\
\hline & \multirow{8}{*}{ Társadalomstatisztika } & Munkaerőpiac \\
\hline & & Jövedelmi viszonyok, életkörülmények \\
\hline & & Lakás, kommunális ellátás \\
\hline & & Egészségügy, baleset \\
\hline & & Szociális védelem \\
\hline & & Oktatás \\
\hline & & Kultúra \\
\hline & & Igazságszolgáltatás \\
\hline \multirow{14}{*}{ Gazdaságstatisztika } & \multirow{8}{*}{ Makrogazdaság-statisztika } & Nemzeti számlák \\
\hline & & Beruházás \\
\hline & & Gazdasági és nonprofit szervezetek \\
\hline & & Kutatás-fejlesztés \\
\hline & & Külkereskedelem \\
\hline & & Árak \\
\hline & & Pénzügyek \\
\hline & & Energiagazdálkodás \\
\hline & \multirow{6}{*}{ Gazdasági ágazatok statisztikája } & Mezögazdaság \\
\hline & & Ipar, építőipar \\
\hline & & Belkereskedelem \\
\hline & & Turizmus, vendéglátás \\
\hline & & Szállítás, közlekedés \\
\hline & & Információ, kommunikáció \\
\hline Környezetstatisztika & Környezetstatisztika & Környezet \\
\hline Nem besorolható & Nem besorolható & Nem besorolható \\
\hline
\end{tabular}


A témakörök között nem szerepeltetjük külön a területi és a nemzetközi összehasonlításokat. Amennyiben egy területi vagy nemzetközi vizsgálatot tartalmazó táblázat esetén nem tudtuk egyértelmüen megállapítani, hogy az társadalom- vagy gazdaságstatisztikai adatközlést tartalmaz-e, a táblázat a nem besorolható kategóriába került.

A magyar statisztikai évkönyveket fejezetek és táblázatok szintjén, autopszia alapján dolgoztuk fel. Minden kötet esetében meghatároztuk, hogy benne az egyes altémakörök hány fejezettel, illetve táblázattal szerepelnek. A táblázat szintű feldolgozás - bár az adatgyüjtést meglehetősen nehezítette - nem elkerülhető, mivel az évkönyvek mindenkori szerkezetében gyakori, hogy egy-egy fejezet csupán 3-4 táblázatot, más fejezetek viszont száznál is többet közölnek. Így azonos fejezetszám mellett az eltérő táblázatszámok segíthetnek a szakstatisztikák közötti hangsúlyok értékelésében. A táblázatszintü feldolgozás tehát mindenképpen szükséges volt, azonban még ebben az esetben is több nehézség jelentkezett az adatbázis összeállítása során.

A feldolgozást az egyes fejezetek átmeneti összevonása és szétválasztása tette bonyolulttá. Voltak időszakok, amikor az évkönyvekben külön fejezetekben, míg másokban összevontan közölték például a népesedésre és a népmozgalomra vagy a kultúrára és az oktatásra vonatkozó adatokat. A teljesség igénye nélkül, szemléltetés céljából közöljük, hogy 1980-tól húsz éven keresztül milyen változások történtek ebben a tekintetben:

- 1980-ban mindössze egyetlen évre összevonták a szociális védelem és az egészségügy témákat, hogy 1981-ban ismét önállóan adják őket közre.

-1981-ben elöször jelentek meg önállóan kutatás-fejlesztési és számítástechnikai adatokat tartalmazó fejezetek.

- 1982-ben elöször került be a kiadványba a gazdasági szervezetek adataira vonatkozó fejezet.

- 1985-ben összevonták a népesség és a népmozgalom fejezeteket.

- 1986-ban a kommunikációs adatokat „leválasztották” a közlekedésről; egyetlen évig függelékbe kerültek az időjárási és a nemzetközi adatok.

- 1988-ban különvált a kultúra és a sport fejezete.

- 1990-ben újra összevonták a közlekedést és a kommunikációt, valamint az egészségügyet és a szociális ellátást.

- 1991-ben újfent összeolvasztották a sport és a kultúra adatait közlö fejezeteket.

- 1994-ben ismét szétválasztották az egészségügy és a szociális ellátás adatait; egy év erejéig más fejezetbe építették be a számítástechnikával foglalkozó fejezetet. 
- 1995-ben újra megjelent az önálló számítástechnikai fejezet, és napvilágot látott egy áradatokat önállóan közlö fejezet is.

-1996-ban ismét különváltak a kommunikáció és a közlekedés adatait tartalmazó fejezetek.

Hasonló, fejezeteket érintő változások a statisztikai évkönyv történetének minden időszakában előfordultak, a tizenkilencedik századi átalakításokról Bokor [1896], a két világháború közötti módosításokról Surányi-Unger [1944] számol be részletesen. Mindketten ismertetik a statisztika adott korban elfogadott tematikai felosztását is.

Egy másik probléma, hogy az elmúlt csaknem 150 év során a statisztikai kiadványok szerkezetére hatással volt a korabeli besorolások változása. Például az öngyilkosságra vonatkozó adatokat váltakozva hol a népmozgalom, hol az egészségügy, hol a baleset, hol a szociális viszonyok témaköréhez sorolták. Hasonlóan, a bölcsödékre vonatkozó adatok is némelykor az egészségügy, máskor a szociális ellátás témában kaptak helyet. Jelen tanulmány egyik célja, hogy azonosítsa az egyes korokban a hivatalos statisztika által előnyben részesített témaköröket. Így nem rendezhettük át a mai szemmel furcsának ható besorolásokat a jelenlegi értelmezésnek megfelelő alkategóriák szerint, hanem ragaszkodnunk kellett a korabeli csoportosításokhoz. (Vizsgálatunk értelmét vesztené, ha például az öngyilkosságra vonatkozó adatokat, amelyek egyes korok statisztikusai szerint a balesetekhez tartoztak, a népmozgalomba sorolnánk át.) Az összehasonlíthatóság céljából mindössze a fejezeteket rendszereztük mai megfelelöik alapján.

A fejezetek elválasztása során igyekeztünk következetesek lenni, ám ezt az évkönyvek tipográfiai megoldásai nem minden esetben segítették elő. Míg a számozott fejezetek esetén egyértelmü volt a dolgunk, a fejezetszámozás nélküli köteteknél a tipográfiailag egyértelmüen elkülönülő részeket tekintettük fejezeteknek, az egyes hierarchiaszinteket pedig a korban legközelebb eső évkönyvhöz igazítottuk.

A feldolgozás során nem vettük figyelembe a függelékként közölt táblázatokat, azonban számoltunk azokkal a területi és nemzetközi adatokra vonatkozó adatközlésekkel, amelyek a szövegtest részét képezik.

Nem dolgoztuk fel a csonka 1889. és 1890. tárgyévi köteteket. Az összevont (háborús) köteteknél meghagytuk az összevont tárgyévet. Nem összevontként, hanem 1955-höz sorolva szerepeltetjük azonban az 1949-1955. tárgyévvel megjelent kötetet, amely csak azért közli hat év adatait, mert a korábbi évek kiadványai nem voltak nyilvánosak. 


\section{Eredmények}

A Magyar statisztikai évkönyv 131 kötetét feldolgozó adatbázis 4460 adatcellából áll, és minden kötet esetén tartalmazza az egyes témakörökhöz tartozó fejezetek, illetve táblázatok számát. A vizsgálat során összesen 2902 fejezetet és 57159 táblázatot sikerült azonosítani.

A következő táblázatok a fejezetek és a táblázatok számosságát, illetve arányait mutatják be fö témakörönként.

2. táblázat

\begin{tabular}{c|c|c|c|c}
\multicolumn{4}{c}{ A fejezetek átlagos száma egy évkönyvben fö témakörönként, $1871-2015$} \\
\hline \multirow{2}{*}{ Időszak } & \multicolumn{4}{|c}{ Fö témakör } \\
\cline { 2 - 5 } & $\begin{array}{c}\text { Népesedés } \\
\text { és társadalom }\end{array}$ & Gazdaság & Környezet & Egyéb \\
\hline 871-1888 & 3,67 & 5,44 & 0,17 & 1,67 \\
\hline $893-1918$ & 6,87 & 8,08 & 1,00 & 2,71 \\
\hline $919-1946$ & 7,75 & 9.65 & 0,95 & 1,90 \\
\hline $947-1989$ & 9,82 & 12,02 & 1,05 & 2,49 \\
\hline $990-2015$ & 9,50 & 14,81 & 1,62 & 3,35 \\
\hline $871-2015$ & 8,05 & 10,59 & 1,02 & 2,50 \\
\hline
\end{tabular}

Megjegyzés. Itt és a további táblázatokban a tárgyéveket tüntettük fel.

Forrás: Itt és a továbbiakban saját számítás.

3. táblázat

A táblázatok átlagos száma egy évkönyvben fö témakörönként, 1871-2015

\begin{tabular}{c|c|c|c|c}
\hline \multirow{2}{*}{ Időszak } & \multicolumn{4}{|c}{ Fö témakör } \\
\cline { 2 - 5 } & $\begin{array}{c}\text { Népesedés és } \\
\text { társadalom }\end{array}$ & Gazdaság & Környezet & Egyéb \\
\hline \multirow{2}{*}{$1871-1888$} & 50,83 & 66,56 & 1,00 & 6,00 \\
\hline $1893-1918$ & 198,71 & 284,29 & 1,79 & 23,54 \\
\hline $1919-1946$ & 102,95 & 167,70 & 1,00 & 13,20 \\
\hline $1947-1989$ & 220,70 & 236,26 & 5,70 & 50,09 \\
\hline $1990-2015$ & 253,31 & 226,15 & 20,46 & 76,04 \\
\hline $1871-2015$ & 181,82 & 209,27 & 6,55 & 38,69 \\
\hline
\end{tabular}


A fejezetek átlagos száma egy évkönyvben témakörönként, 1871-2015

\begin{tabular}{c|c|c|c|c|c|c}
\hline \multirow{2}{*}{ Időszak } & \multicolumn{6}{|c}{ Témakör } \\
\cline { 2 - 7 } & Népesedés & Társadalom & Makrogazdaság & Gazdasági ágak & Környezet & Egyéb \\
\hline $1871-1888$ & 1,00 & 2.67 & 2,39 & 3,06 & 0,17 & 1,67 \\
\hline $1893-1918$ & 2,96 & 3,92 & 3,92 & 4,17 & 1,00 & 2,71 \\
\hline $1919-1946$ & 3,00 & 4,75 & 4,90 & 4,75 & 0,95 & 1,90 \\
\hline $1947-1989$ & 1,89 & 7,93 & 4,23 & 7,79 & 1,05 & 2,49 \\
\hline $1990-2015$ & 1,00 & 8,50 & 7,42 & 7,38 & 1,62 & 3,35 \\
\hline $1871-2015$ & 1,95 & 6,10 & 4,66 & 5,93 & 1,02 & 2,50 \\
\hline
\end{tabular}

5. táblázat

A táblázatok átlagos száma egy évkönyvben témakörönként, 1871-2015

\begin{tabular}{c|c|c|c|c|c|c}
\hline \multirow{2}{*}{ Időszak } & \multicolumn{7}{|c}{ Témakör } \\
\cline { 2 - 7 } & Népesedés & Társadalom & Makrogazdaság & Gazdasági ágak & Környezet & Egyéb \\
\hline \multirow{2}{*}{$1871-1888$} & 7,06 & 43,78 & 21,44 & 45,11 & 1,00 & 6,00 \\
\hline $1893-1918$ & 66,00 & 132,71 & 71,67 & 212,63 & 1,79 & 23,54 \\
\hline $1919-1946$ & 47,30 & 55,65 & 63,55 & 104,15 & 1,00 & 13,20 \\
\hline $1947-1989$ & 49,00 & 171,70 & 51,40 & 184,86 & 5,70 & 50,09 \\
\hline $1990-2015$ & 52,42 & 200,88 & 100,50 & 125,65 & 20,46 & 76,04 \\
\hline $1871-2015$ & 46,77 & 135,05 & 62,60 & 146,67 & 6,55 & 38,69 \\
\hline
\end{tabular}

6. táblázat

A népesesedés és társadalom, valamint a gazdaság fö témakörökkel foglalkozó táblázatok számának összes táblázathoz viszonyitott aránya, 1871-2015 (százalék)

\begin{tabular}{l|c|c}
\hline \multirow{2}{*}{ Időszak } & \multicolumn{2}{|c}{ Fő témakör } \\
\cline { 2 - 3 } & Népesedés és társadalom & Gazdaság \\
\hline \multirow{2}{*}{$1871-1888$} & 40,87 & 53,51 \\
\hline $1893-1918$ & 39,09 & 55,93 \\
\hline $1919-1946$ & 36,14 & 58,87 \\
\hline $1947-1989$ & 43,04 & 46,08 \\
\hline $1990-2015$ & 43,98 & 39,27 \\
\hline $1871-2015$ & 41,67 & 47,96 \\
\hline
\end{tabular}


Az egyes időszakokban tehát szinte kivétel nélkül a gazdasági adatokat közlő táblázatok voltak túlsúlyban. Meglepő módon ez a tendencia éppen a szocializmus időszakában kezdett gyengülni, hogy 1989 után a Magyar statisztikai évkönyv történetében először több népesedésre és társadalomra vonatkozó táblázat jelenjen meg, mint gazdaságra vonatkozó. A következökben a két fö témakör százalékos arányát mutatjuk be.

A népesedésre és társadalomra vonatkozó táblázatok számának aránya az összes táblázaton belül a két világháború között volt a legalacsonyabb. Ugyanakkor a témakör viszonylagos stabil százalékos aránya (36-44 százalék) figyelhető meg szemben a gazdaságéval (39-59 százalék). Az értékek változását tehát elsősorban a gazdasági témák iránti érdeklődés élénkülése és lanyhulása határozta meg a népesedési és társadalmi táblázatok arányának viszonylagos stabilitása mellett. Ezt támasztja alá az is, hogy bár 1990 után az utóbbi megelőzte a gazdasági táblázatok arányát; összességében mégsem érte el az 50 százalékot.

Nehéz megragadni azokat a mozzanatokat, amikor a két fö témakör közül az egyik érezhetően markánsabbá vált a másikhoz képest. „Hektikus” időszakokban évről évre jelentős arányváltozások figyelhetők meg, amelyek azonban nem minden esetben jelentettek tartós változást. Így például 1938 után a népesedési-társadalmi és a gazdasági témák aránya meglehetősen gyakran és rendszertelenül változott - olykor jelentős eltéréseket okozva az évkönyv szerkezetében.
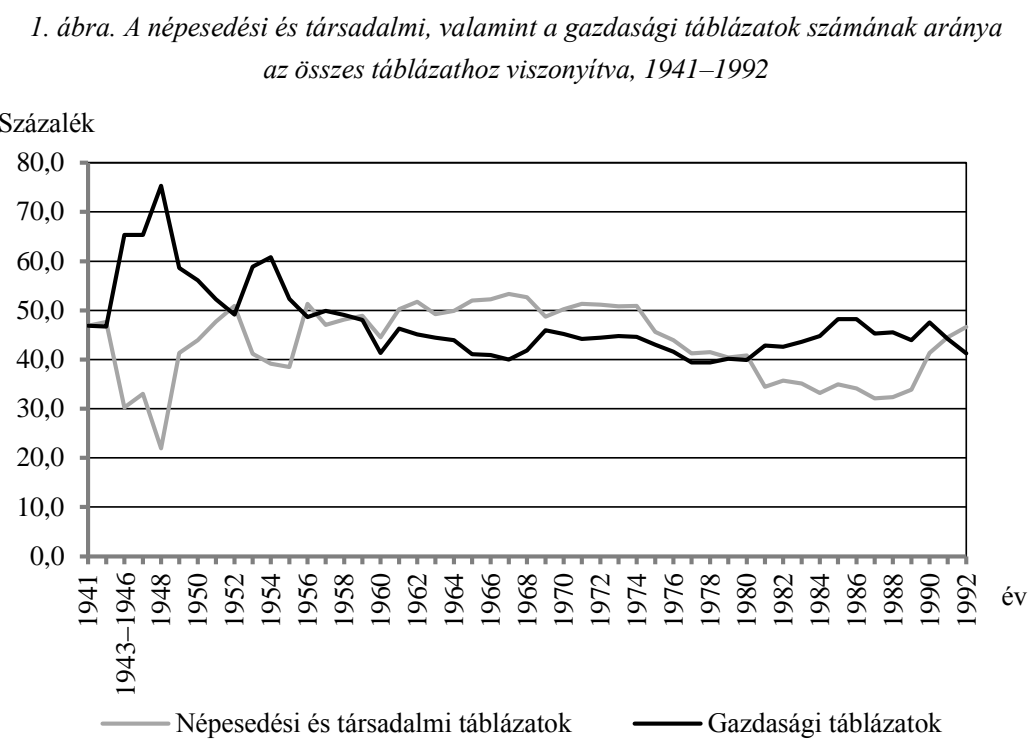

A táblázatok évi átlagos száma 1872 és 2016 között 436 volt. A legtöbbet az 1980-as években közölték, amikor az 1978-1980-as és 1987-1988-as időszakban - 
elsősorban a területi és nemzetközi adatsorok nagy számának köszönhetően - rendre több mint 650-et tettek közzé. Népesedés és társadalom témában táblázatok a legnagyobb számban az 1970-es években jelentek meg: a statisztikai évkönyvekben 1971 és 1973 között 288-289 darab. A gazdasági táblázatok száma az 1900-as évek elején rendszeresen meghaladta a háromszázat, a legtöbbet, 358-at azonban 1948-ban közölték.

Az altémakörök közül az ipar, építőipar évi átlagos táblázatszáma a legmagasabb (45,3), míg az áraké, a környezeté és az energiagazdálkodásé tíz alatt marad. (Lásd a 7. táblázatot.) Ezekből az adatokból azonban nem lehet levonni messzemenő következtetéseket, hiszen az egyes altémakörök rendszertelen összevonása és szétválasztása jelentősen torzíthatja az adatokat. Az egészségügy és a szociális ellátás több évtizeden keresztül összevont témaként jelent meg, ami jelentősen emeli az egészségügy, balesetek alkategória átlagos táblázatszámát, de hasonló hatást gyakorolt a kulturális, sport- és oktatási témák évtizedekig tartó összevonása is a kultúra, sport altémakör átlagos táblázatszámára. A nem besorolható altémakör magas átlagos táblázatszáma elsősorban az 1980-as és kétezres évek gyakorlatának köszönhető, amikor minden statisztikai évkönyv száznál több területi, illetve nemzetközi adatokat bemutató táblázatot közölt.

7. táblázat

A táblázatok évi átlagos száma altémakörönként, 1871-2015

\begin{tabular}{|c|c|c|c|}
\hline Altémakör & Átlagos táblázatszám & Altémakör & Átlagos táblázatszám \\
\hline Ipar, építőipar & 45,30 & Jövedelmi viszonyok, életkörülmények & 18,36 \\
\hline Szállítás, közlekedés & 43,46 & Munkaerőpiac & 17,91 \\
\hline Nem besorolható & 42,23 & Turizmus, vendéglátás & 15,23 \\
\hline Mezőgazdaság & 41,32 & Információ, kommunikáció & 13,83 \\
\hline Népmozgalom & 40,30 & Külkereskedelem & 12,76 \\
\hline Kultúra, sport & 34,22 & Gazdasági és nonprofit szervezetek & 12,00 \\
\hline Oktatás & 31,57 & Lakás, kommunális ellátás & 11,41 \\
\hline Egészségügy, baleset & 29,30 & Kutatás-fejlesztés & 10,29 \\
\hline Pénzügyek & 25,69 & Belkereskedelem & 10,06 \\
\hline Igazságszolgáltatás & 24,24 & Árak & 9,51 \\
\hline Népesség & 21,54 & Környezet & 8,02 \\
\hline Nemzeti számlák, beruházás & 20,40 & \multirow{2}{*}{ Energiagazdálkodás } & \multirow[t]{2}{*}{7,31} \\
\hline Szociális védelem & 18,65 & & \\
\hline
\end{tabular}

Az ipar, építőipar altémakör „tetőzése” az elvárásoknak megfelelően a szocializmus időszakára esik: az 1970-es években rendszeresen hetvennél több táblázat jelent 
meg ebben a kategóriában. Korábban is előfordult egyes években kiemelten magas táblázatszám ipari témákban, azonban az többéves időszakokat tekintve a hetvenes évekig nem vált rendszeressé. Az átlagokhoz képest az ipari táblázatok számának összes táblázathoz viszonyított százalékos aránya némiképp másképp alakult. A szocializmus időszaka a leghosszabb összefüggő szakasz, amikor az ilyen jellegü táblázatok száma közel 15 százaléka volt az évkönyvek összes táblázatának: 1949 és 1954, illetve 1957 és 1964 között minden kötet esetén az ipari táblázatok a kiadvány táblázatainak több mint hetedét adták. A hetvenes és a nyolcvanas években az ipari táblázatok aránya fokozatosan 10 százalék alá esett. Az ipari adatok közlésének mélypontját egyértelműen a kétezres évek jelentik; ekkor vált ugyanis rendszeressé az az 1990-es években indult tendencia, hogy az ipari táblázatok az évkönyvek öszszes táblázatának csak kevesebb mint huszadát teszik ki.

A mezőgazdaság esetén a tendenciák nem ennyire egyértelműek, bár a 8. táblázatban látható, hogy a legtöbb, ehhez az altémakörhöz tartozó táblázat az 1900-as évek elején jelent meg. Az évkönyvenkénti átlagos táblázatszám a szocializmus időszakában is meglehetősen magas maradt, és ugyan a rendszerváltás után csökkenésnek indult, mégsem olyan mértékben esett vissza, mint ami az ipar esetén volt tapasztalható. Az 1920-as évek végén és az 1930-as években rendszeresen előfordult, hogy a mezőgazdasági adatokat közlő táblázatok az évkönyvek táblázatainak 17 százalékát tették ki, míg az 1995 utáni években csak kevesebb, mint 5 százalékát.

8. táblázat

A táblázatok átlagos száma egy évkönyvben, 1871-2015

\begin{tabular}{l|c|c}
\hline \multirow{2}{*}{ Időszak } & \multicolumn{2}{|c}{ Altémakör } \\
\cline { 2 - 3 } & Mezögazdaság & Ipar, épitőipar \\
\hline $1871-1888$ & 17,39 & 20,89 \\
\hline $1893-1918$ & 62,00 & 59,33 \\
\hline $1919-1946$ & 46,20 & 35,50 \\
\hline $1947-1989$ & 45,19 & 64,16 \\
\hline $1990-2015$ & 28,65 & 25,58 \\
\hline $1871-2015$ & 41,32 & 45,30 \\
\hline
\end{tabular}

A mezőgazdasággal, valamint az iparral és építőiparral kapcsolatos táblázatok számának és arányának csökkenése többek között más gazdasági ágak fokozott térnyerésének köszönhetö. A kutatás-fejlesztéssel, az informatikával, az árakkal, az energiagazdálkodással, a belkereskedelemmel és a turizmussal foglalkozó témák az 1980-as években kezdtek rendszeressé és jelentőssé válni a statisztikai évkönyv adatközléseiben. 
A vizsgált időszakban gyakori volt a szállitás, közlekedés altémakör (melynek sokáig a hírközlés is része volt) táblázatszámának magas értéke. Az 1880-as évek óta minden évben a táblázatok több mint 5 százaléka erről jelent meg. Százalékos arányuk az 1890-es és az 1900-as években tetőzött, ugyanakkor soha sem haladta meg a 20 százalékot. Ez utóbbi ellenére mégis megállapíthatjuk, hogy a gazdasági ágazatok közül legstabilabban a szállítás, közlekedés őrizte meg pozícióját az évek során.

A két világháború időszakában nem jelent meg több társadalomstatisztikai táblázat, és hasonlóan, a szocializmus időszakában sem jelent meg több gazdaságstatisztikai. Nem okoztak egyszeri, jól érzékelhető trendváltozást az évkönyvek szerkezetében a gazdasági világválságok és a demográfiai válságok. A szerkezeti változások inkább a rendszerváltásokhoz köthetők. Így a gazdasági táblázatok száma az 192933-as és a 2008. évi gazdasági válságot követően sem nőtt jelentősen, az 1989-90-es rendszerváltás után viszont azonnal csökkenni kezdett.

A Magyar statisztikai évkönyvvel ellentétben a hivatal az évközi kiadványokban talán könnyebben nyomon követte a társadalmi és gazdasági változások okozta adatigényeket. Ezért - mint azt már említettük - bár a 2008. évi gazdasági válság nem gyakorolt hatást az évkönyvek szerkezetére, a Statisztikai tükör sorozatban megjelent kiadványok között érzékelhetően élénkültek a gazdasági témák. E sorozatban 2007 és 2016 között 269 kiadvány jelent meg, melyek tematikus besorolása rámutat arra, hogy szerkezetük sokkal gyorsabban reagált a társadalmi és a gazdasági változásokra. ${ }^{2}$

9. táblázat

A Statisztikai tükör kiadványok száma témakörönként, 2007-2016

\begin{tabular}{l|c|c}
\hline \multirow{2}{*}{ Megjelenés éve } & \multicolumn{2}{|c}{ Fő témakör } \\
\cline { 2 - 3 } & Népesedés és társadalom & Gazdaság \\
\hline \multirow{2}{*}{2007} & 24 & 11 \\
\hline 2008 & 32 & 31 \\
\hline 2009 & 26 & 38 \\
\hline 2010 & 31 & 37 \\
\hline 2011 & 31 & 36 \\
\hline 2012 & 30 & 39 \\
\hline 2013 & 29 & 35 \\
\hline 2014 & 37 & 46 \\
\hline 2015 & 39 & 19 \\
\hline 2016 & 25 & 16 \\
\hline
\end{tabular}

${ }^{2}$ Köszönettel tartozom $C z$. Tóth Jánosnak a Statisztikai tükör kiadványsorozatra vonatkozó adatok feldolgozásában nyújtott segítségéért.

Statisztikai Szemle, 95. évfolyam 11-12. szám 
A 9. táblázat szerint a két fő témakör nem egyforma hangsúllyal jelent meg a Statisztikai tükör sorozatban 2007 és 2016 között. A gazdasági kiadványok száma a 2008. évi gazdasági világválság után jelentősen megugrott, a gazdasági témák háttérbe szorulása és a népesedési-társadalmi témakörrel foglalkozó kiadványok számának növekedése pedig az után következett be, hogy az európai demográfiai válság egyre nagyobb sajtóvisszhangot kapott a 2010-es években. A társadalmi jelenségek, adatigények és a KSH kiadványpolitikájának kapcsolata természetesen a jelenleginél jóval részletesebb vizsgálatot kívánna.

2. ábra. A népesedési és társadalmi, valamint a gazdasági témákkal foglalkozó Statisztikai tükör kiadványok éves százalékos aránya a sorozat összes kiadványához viszonyítva, 2007-2016

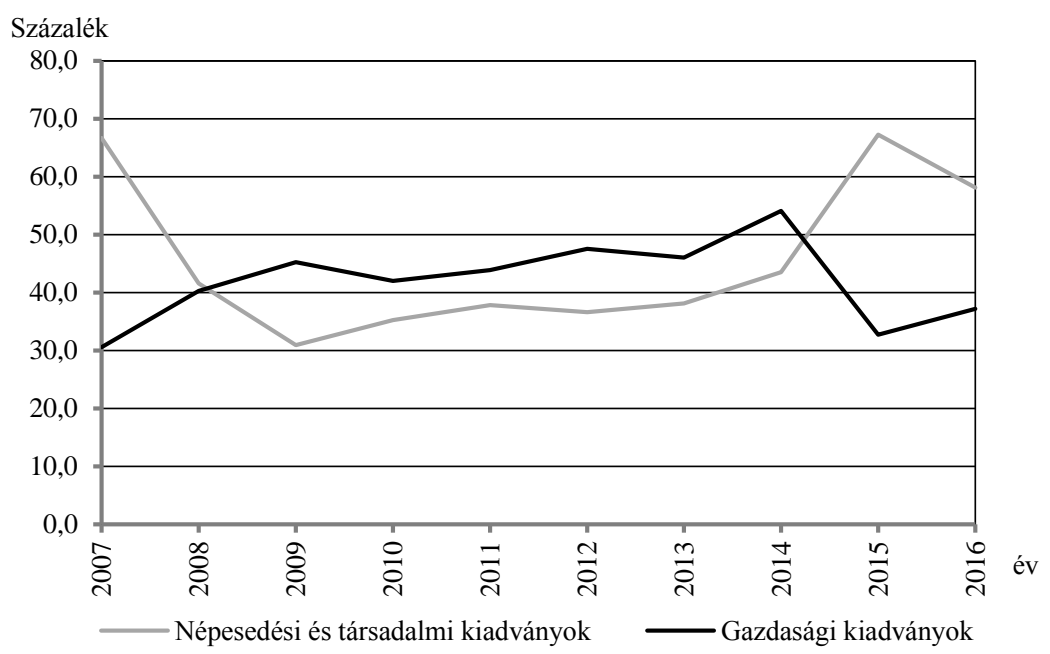

\section{4. Összegzés}

Bár a Magyar statisztikai évkönyv a KSH mindenkori legfontosabb kiadványsorozata, szerkezeti változásainak vizsgálata eddig hiányzott a hazai szakirodalomból. Az évkönyvek táblázatszintủ feldolgozása rávilágított a különböző témakörök közlését jellemző tendenciákra, például az iparra vonatkozó táblázatok térnyerésére az 1970-es években, a mezőgazdaságról szóló táblázatok háttérbe szorulására a huszadik század második felében, a népesedési-társadalmi és a gazdaságstatisztikai táblázatok korszakonként változó számára, illetve egy-egy szakstatisztika tartós megjelenésére a „hivatalos kánonban”. 
Az évkönyvek szerkezete további kutatási lehetőségeket rejt magában. A jövőben érdemes lenne összehasonlítani az általunk vizsgált korszak nemzetközi gyakorlatát, részletesen elemezni a különbözö szakstatisztikák megjelenését a kiadványokban, illetve szerkezeti szempontból vizsgálni a KSH más kiadványsorozatait vagy teljes kiadványportfólióját.

\section{Irodalom}

BoKOR G. [1896]: A magyar hivatalos statisztika fejlődése és szervezete. Országos M. Kir. Statisztikai Hivatal. Budapest.

BudAy L. [1915]: Előszó. In: Magyar statisztikai évkönyv, 1913. Magyar Kir. Központi Statisztikai Hivatal. Budapest. III-IV. old.

Dobrovits S. [1940]: Előszó. In: Magyar statisztikai évkönyv, 1939. Magyar Kir. Központi Statisztikai Hivatal. Budapest. I. old.

GYÖRGY A. [1885]: Magyarország hivatalos statisztikája. Athenaeum. Budapest.

KeLETI K. [1868]: A statistika hivatalos és tudományos mivelése. Eggenberger. Pest.

KELETI K. [1869]: Emlékirat egyúttal javaslat Magyarország hivatalos statistikájának szervezése tárgyában. Athenaeum. Pest.

KSH (KözPOnTI StatiszTiKai Hivatal) [1986]: Ismertető a Központi Statisztikai Hivatalról. Budapest.

KSH [1991]: A Központi Statisztikai Hivatal múltja, jelene, jövője. Budapest.

KSH [1997]: Ismertetö a Központi Statisztikai Hivatalról. Budapest.

KSH [2010]: A Magyar statisztikai évkönyv készitése. Budapest.

PiKLER Gy. [1949]: Előszó. In: Magyar statisztikai évkönyv, 1947. Központi Statisztikai Hivatal. Budapest. [III]. old.

SURÁNYI-Unger T. [1944]: A Magyar Statisztikai Évkönyv továbbfejlesztése. Magyar Statisztikai Szemle. 22. évf. 7-8. sz. 319-347. old.

SzABÓKY A. [1924]: Előszó. In: Magyar statisztikai évkönyv, 1916, 1917, 1918. Magyar Kir. Központi Statisztikai Hivatal. Budapest. III-IV. old.

Vuкоvich G. [2010]: Bevezetés. In: Magyar statisztikai évkönyv, 2009. Központi Statisztikai Hivatal. Budapest. V. old.

Vukovich G. [2013]: Bevezetés. In: Magyar statisztikai évkönyv, 2012. Központi Statisztikai Hivatal. Budapest. V. old.

\section{Summary}

The Statistical Yearbook of Hungary published since 1872 is the flagship publication of the Hungarian Central Statistical Office. The paper describes briefly the historical background of the publication as a significant part of the history of Hungarian statistics. Studying the structure of the yearbook makes it possible to analyse the role and importance of the various statistical subject categories in the last 150 years.

Statisztikai Szemle, 95. évfolyam 11-12. szám 